\title{
AGAINST THEOLOGICAL FICTIONALISM
}

\section{ROGER POUIVET}

\author{
University of Lorraine
}

\begin{abstract}
According to theological fictionalism, God has the same status as a fictional character in a novel or a movie. Such a claim has been defended by Robin Le Poidevin on the basis of Kendall Walton's theory of make-believe. But it is not only a philosophical esoteric account of religious beliefs, it is now an exoteric view, sometimes accepted by "believers" themselves, and so could even be considered a postmodern heresy. But theological fictionalism does not work: faith is real assent and not make-believe; belief is different from acceptance; belief and faith are dispositional, but make-believe seems to presuppose an account of beliefs as occurrent states; we cannot anymore imagine at will than we can believe at will.
\end{abstract}

\section{INTRODUCTION}

Theological fictionalism maintains that religious monotheistic commitment does not necessitate the truth of theism. According to this position, God could have the same ontological status as a fictional character in a novel or a movie. Such a character does not exist; we know that that character does not exist; but we think about this character and experience emotions (or quasi-emotions) about it and what it does. Like the experience of fiction, religious experience could consist in a game of make-believe. Robin Le Poidevin defends such a theological fictionalism (without using this label) in chapter 8 ("Is God a Fiction?") of Arguing for Atheism, ${ }^{1}$ partly inspired by Kendall Walton's theory of make-believe. ${ }^{2}$

\footnotetext{
${ }^{1}$ Robin Le Poidevin, Arguing for Atheism (London: Routledge, 1996).

${ }^{2}$ Kendall L. Walton, Mimesis as Make-Believe (Cambridge, MA, and London: Harvard University Press, 1990).
} 
In the first section of this paper, I will review Le Poidevin's version of theological fictionalism.

But theological fictionalism is not simply a theory held by philosophers. It also appears to be widespread in Post-modern cultures. The assumption is that we do not have to accept full-blooded theological realism - that God exists, that He revealed himself, that Christ was resurrected, and so on - in order to be religious persons. Such realist claims, it is thought, have been definitively disproven in the post-Enlightenment period, thanks to the human and social sciences. My second point will consist in inspecting this postmodernist flowering of theological fictionalism.

Fictionalism was already recognized in the Dogmatic Constitution of the Catholic Faith, in the text known under the name of its Latin headwords, Dei Filius:

Even the Holy Scriptures, which had previously been declared the sole source and judge of Christian doctrine, began to be held no longer as divine, but to be ranked among the fictions of mythology.

This indicates that theological fictionalism is the outcome of a modernist view of faith, condemned by the Church if not refuted, but capable of reappearing in new and different guises. The main error of this theory is that it supposes a non-doxastic account of faith. Faith would not imply full belief, but only quasi-belief or quasi-acceptance. But there is, inescapably, a strong doxastic component in faith. And unlike acceptance, belief is essentially realistic.

\section{COMPENDIUM OF THEOLOGICAL FICTIONALISM}

To explain the position that I call theological fictionalism, Le Poidevin makes use of a debate in the philosophy of science over the status of theoretical entities. Within this debate, he distinguishes realism, instrumentalism and positivism and proposes corresponding views about religious matters.

Realism. According to realism, scientific theories are to be taken at face value. If they appear to refer to entities in the world called "neutrons", then this is what they do. Theological realism is the view that statements about God refer to a transcendent being. Such statements are descriptive and so are true or false. 
Instrumentalism. Theories, according to instrumentalism, are merely useful devices we use to make predictions about how things will behave. So, the entities referred to in theories may just be fictions. Theological instrumentalism says that discourse about God is purely fictional. But the predictive dimension is largely beside the point in theological instrumentalism, unless we have in mind predicting the behaviour of religious persons, which may be anticipated through knowing what they believe.

Positivism. Theories, according to positivism, are either true or false (and so positivism differs from instrumentalism in this respect); but (in contrast with realism) theories have not to be taken at face value. Theological positivism says that discourse apparently about God is true, but what it describes, in symbolic language, are truths about our moral and psychological lives.

What I call "theological fictionalism" Le Poidevin calls "theological instrumentalism". I think that "theological fictionalism" is a better name, because the notion of fiction is central to explaining how this kind of view works. Le Poidevin relies heavily upon Walton's theory of fiction as make-believe. According to Walton,

just as a child make-believes that a group of chairs set in a line is a bus, or that, in chasing after a friend, he is chasing after a desperate criminal, armed to the teeth with a pop-gun and a water pistol, so we, in reading a novel, make-believe that it is reporting the truth. In doing so we, as it were, locate ourselves in the novel. We are there, witnessing the events. We may even assign ourselves a role, and imagine talking to the characters. It is our active participation in the fiction which explains why we become emotionally involved. ${ }^{3}$

Le Poidevin adds:

Walton's solution of the paradox that we can be emotionally involved in something we know to be false is that we play a game of make-believe in which the fiction becomes reality, and part of the game is to feel something akin to real emotions, though they are not the genuine article. ${ }^{4}$

\footnotetext{
${ }^{3}$ Kendall L. Walton, Mimesis as Make-Believe, p. 116.

${ }^{4}$ Robin Le Poidevin, Arguing for Atheism, p. 117.
} 
Theological fictionalism is thus the thesis that to engage in religious practice is to engage in a game of make-believe:

We make-believe that there is a God, by reciting, in the context of the game, a statement of belief. We listen to what make-believedly are accounts of the activities of God and his people, and we pretend to worship and address prayers to that God. In Walton's terms, we locate ourselves in that fictional world, and in so doing we allow ourselves to become emotionally involved, to the extent that a religious service is capable of being an intense experience. [...W]e are presented with a series of dramatic images: an all-powerful creator, who is able to judge our moral worth, to forgive us or to condemn, who appears on Earth in human form and who willingly allows himself to be put to death. What remains, when the game of make-believe is over, is an awareness of our responsibilities for ourselves and others, of the need to pursue spiritual goals, and so on. ${ }^{5}$

So, according to theological fictionalism, Christians are not believers, but make-believers; they play with a fictional religious world as children play with toy cars, readers with narratives, and filmgoers with moving images. This can be important for their lives, the sense they have of themselves and of their relations with others, and their sense of morality and spirituality. But definitively, they do not have to claim what they believe to be true about someone or something, and they do not even have to believe anything. They are simply engaged in making sense of stories, characters, interpretations, and so on.

\section{THEOLOGICAL FICTIONALISM AS A POSTMODERN HERESY}

Theological fictionalism may seem attractive to those who want to preserve what they think of as the spiritual and moral content of religion but who do not accept an ontological commitment to a transcendent being or realist claims about Christ's resurrection, miracles, the Day of Judgment, and so on. Theological fictionalism says, in short, that you can be a Non-Metaphysical Christian. God can still be viewed positively as the greatest single creation of the imagination. Anthony Kenny suggests that "set beside the idea of God, the most original inventions

${ }^{5}$ Ibid., p. 119. 
of mathematicians and the most unforgettable characters in drama are minor products of the imagination; Hamlet and the square root of minus one pale into insignificance by comparison". ${ }^{6}$

Fictionalist theology gives sense to the claim that Christ was resurrected, for example, by saying that it is "true in the Gospels", "true for those you accept to make sense of a certain story", or "true in religion". That Christ was resurrected would be a quasi-assertion. To quasi-assert that $p$ is to express one's acceptance of $p$, an attitude that is compatible with agnosticism and disbelief. Quasi-assertion is grounded mainly in non-doxastic or non-epistemic reasons, and recourse to this device encourages a non-cognitivist account of religious matters. Arguably, quasi-assertion is grounded in pragmatic reasons, especially to provide comfort to oneself and to make one's life easier to live. To accept that Christ was resurrected is not to believe it, as we believe for example that Cracow is in Poland or that the moon is not made of cheese, but it could be very helpful to make-believe it was so.

Theological fictionalism gained credit in Post-modern theology. By post-modern theology, I mean for example Don Cuppitt's account of religion (see Sea of Faith, 1984). ${ }^{7}$ He defends a philosophical view of a broader account which has insinuated itself into theology since the fifties. But this is not simply a philosophical affair. It now has a strong influence on religious people, especially in Western countries. I have no sociological evidence to give, but it seems to me that it is in this way that a lot of Christian Westerners - especially those who have received an academic education - now see theological commitment.

What has developed is a deeply non-cognitivist and non-realistic account of faith. It suggests, first, that there are not religious facts to be discovered, such as the existence of God, or the resurrection of Christ. Secondly, it claims that we create the world through language, and historical realities through narratives. It applies to God what Richard Rorty said about dinosaurs: "Once you describe something as dinosaur, its skin colour and sex life are causally independent of your having so described it. But before you describe it as a dinosaur, or as anything else, there is no sense to the claim that it is 'out there' having properties.

\footnotetext{
${ }^{6}$ Anthony Kenny, Faith and Reason (New York: Columbia University Press, 1983), p. 59.

${ }^{7}$ Don Cuppitt, The Sea of Faith (London: SCM Press, 3rd Revised Edition, 2003).
} 


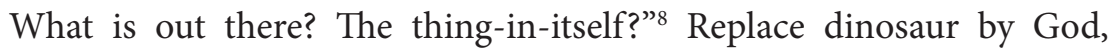
"skin colour" and "sex life" by "all powerful" and "absolutely good", and you have a corresponding non-cognitivist and non-realistic account of Christian religious "truths". Theological fictionalism explain how one could continue to go to Mass, to pray, to participate in the Eucharist, without believing, but only make-believing, in religious matters. What is important finally are not the true facts, but the inward emotions and perhaps some of the behaviours (kindness, generosity, tolerance, etc.) exhibited by Christian make-believers. This corresponds also to what George Lindbeck called the "experiential-expressivist" account of faith. ${ }^{9}$ God is not an object of discourse, but we can make him a condition of discourse (and also a condition of a certain behaviour), by entering into a game of make-believe. And religion is just that.

\section{WHY THEOLOGICAL FICTIONALISM DOES NOT WORK}

Walton says that what fictions make us feel are not emotions, but quasiemotions. He means emotions that do not suppose that we believe in the situation presented in the fiction. If I am frightened by the colour of the sky, which promises a very big thunderstorm, I believe the sky has this colour and that such a sky indicates that there will be a very big thunderstorm. But if I am frightened by a monster on the screen, I do not believe that there is a monster. In fact, I am not afraid; I enter in a game of make-believe about a monster; and I am quasi-afraid, playing at fear, even if I am feeling (phenomenologically) what I would feel in a case of "true" fear. This means that quasi-emotion is a non-doxastic emotion. But perhaps it could also be said that quasi-emotion corresponds to a quasi-belief. I play at believing that there is a monster, and that makes me quasi-afraid.

Aesthetic fictionalism uncouples emotion and belief; theological fictionalism does something parallel and so uncouples faith and belief. We cannot say "I believe that $p$; but not p", as G. E. Moore pointed out. But the theological fictionalist pretends that it is possible to claim: "I have

\footnotetext{
${ }^{8}$ Richard Rorty, "Taylor on Truth" (in J. Tully ed, Philosophy in an Age of Pluralism, Camridge: Cambridge University Press, p. 23).

${ }^{9}$ George Lindbeck, The Nature of Doctrine (Louisville: Westminster John Knox Press, 1984).
} 
faith that $p$; but not $p$ " "To believe" is a factive verb: if I believe that $p$, I am committed to the truth of $p$. But if I have faith in God almighty, it would not be necessary for me to believe in the existence of God: to make-believe would be sufficient. To repeat at the mass that there is a God almighty, or to subscribe to the notion of God almighty Himself, would simply be an emotional prop in a game of make-believe. This would mean that, for faith, quasi-belief and quasi-emotion - the phenomenological content of emotion, without any doxastic component - is all that is needed for our psychological religious life.

But I maintain that this will not do, for it seems for me impossible to "have faith in $G$ " if you do not have faith that $G$ exists. If $S$ has faith in $G$, then $S$ believes that $G$ exists in a way that renders $S$ 's faith in $G$ something other than a game of make-believe. That contemporary Westerners are tempted to replace a realistic and metaphysical account of religious faith by a fictional one does not imply that the epistemology of doing so is coherent. I propose four arguments in favour of this critique of theological fictionalism.

\section{The argument from faith as real assent}

Faith is doxastic, because it supposes to believe that some propositions - those belonging to the Creed in the case of Christian faith - are true. To paraphrase John Henry Newman, a fictionalist belief in God - a belief about a God as a character in a narrative, and not about God as a genuine being - would be like "filial love without the fact of the father". Nobody can place their confidence in Superman, except the inhabitants of Metropolis, who are themselves fictional. The reader or the spectator of Superman adventures cannot place his confidence in Superman, because he does not believe Superman to exist; he may be confident on behalf of the inhabitants of Metropolis, but this has absolutely no real importance, because they are themselves fictional. If Jesus Christ is a fictional character in a game of make-believe, we cannot place our confidence in Him; only characters in the Bible (the apostles for example) could be confident of Him. And so if we understand Jesus Christ to be a fictional character, we do not have faith in Him.

As Newman says in the Grammar of Assent, faith is real assent, and not notional assent. It is not directed to words and stories, but to persons and 
facts. So the notion of fictional assent is useless for characterizing faith in God. Because of the doxastic component of religious faith, to have faith is to believe something, and to believe something means understanding that something to be really the case. It is not to claim that the sense of a certain proposition is deep and existentially moving or quasi-moving, but that Christ is actually the Saviour, for example.

\section{The argument from the difference between belief and acceptance}

Theological fictionalism as it has been presented does not make difference between belief and acceptance. Accepting that $p$, unlike believing that $p$, is akin to a decision - the decision to hold a proposition. This contrasts strongly with the essential non-voluntariness of belief. Faith can be said to be voluntary, but in the sense that it is not against one's will that a person believes in God. Having faith in God's grace is not like being brainwashed. You can refuse to believe in God. But that does not mean that a religious belief is akin to a decision to believe. The doxastic component of faith is non-voluntary, in the sense that I cannot decide to believe in God, any more than I can decide to believe that I speak Chinese or that I am a pumpkin, for example. One can accept a proposition without believing that it is true, and even while believing that it is false, hence contrary to evidence for its truth. But one cannot believe contrary to the evidence of truth. This is the main reason why simulated beliefs or quasi-beliefs are acceptances, and so are not beliefs at all. Simulated beliefs are no more beliefs than fake money is money. I wonder if the notion of make-believe and quasi-emotion are not, in this sense, very ambiguous, suggesting something like a belief, but not exactly, and something close to an emotion, but not quite the same thing.

Many cases of acceptance are cases where someone has evidence for what he accepts; yet he has no full beliefs, but only half-beliefs. In such a case, and for him, a fictional stance may make good sense. If I halfbelieve that $p$, I can simulate that $p$. I can even try to believe, like the libertine who asked, in a famous pensée of Pascal, to go to Mass and to kneel down, hoping that it would make him a genuine Christian. But when we try, that is not faith at all. Aquinas says:

The act of believing ... is firmly attached to one alternative and in this respect the believer is in the same state of mind as one who has science or 
understanding. Yet the believer's knowledge is not completed by a clear vision, and in this respect he is like one having a doubt, a suspicion, or an opinion. ${ }^{10}$

This is not acceptance or half-belief, but a case of certainty without clear vision. There is not room here to discuss the exact nature of faith, but clearly theological fictionalism is deeply in error about its nature.

\section{The argument from the dispositional nature of belief and faith}

Like acceptance, simulated belief in a fictional stance supposes that we play with our own mental state. I know that the monster is in fact an artefact on the screen, but I will behave as if I believed that the monster was in front of me. When someone cries when looking at a movie, and is asked, "Why do you cry, it is only fiction?", the answer could be that the very idea that something like this could happen is sorrowful. And it is not false that we are able to make ourselves sorrowful simply by focusing our mind on sorrowful ideas. So might it be in the religious case: we make ourselves believers by focusing on religious ideas.

Such an account of simulated belief presupposes what Henry H. Price called an "Occurrence Analysis of Belief"."11 To believe something is to have a certain occurrent mental state. In this case we would be able to simulate having a certain mental state or content, without actually having it. Price distinguishes this account from a Dispositional Analysis of Belief, which maintains that beliefs are not occurrent mental states but are rather dispositions to answer a question or to behave in a certain way. This means that if $S$ believes that $p, S$ does not have a specific mental content but rather has a disposition to answer "yes", when asked if p, or the disposition to act according to the fact that p. And in that case, how would simulation be possible?

The doctrine of simulated beliefs presupposes an Occurrence Analysis of Belief. We would be able to simulate because we can simulate having a certain mental state or content. I will not here defend a Dispositional Analysis of Belief, but clearly if such an analysis is correct, or is at least better than an Occurrence Analysis, theological fictionalism is again in a bad position.

\footnotetext{
${ }^{10}$ St Thomas Aquinas, Summa Theologica, IIaIIae, 2, 1.

${ }^{11}$ Henry H. Price, Belief (London: Muirhead Library of Philosophy, 1969).
} 


\section{The argument from the limitations of make-believe}

We saw that we cannot believe at will, but we even cannot imagine at will - contrary to what is often said (on the grounds of a very common romantic account of imagination). I am not at all sure that imagining that God sent us His only son to be crucified, as a Redeemer, to save us from our sins, would be something we could so easily do. This phenomenon I call "modal imaginative resistance". A story is told, but it makes no sense for us, and we don't believe in it and cannot even make-believe in it. I suppose that it is exactly what happens for a lot of unbelievers. They do not think that the religious story is like a novel that makes sense even if it is a fiction. For them, it is like a novel that does not make any sense!

There is a kind of imagination by which we can consider ourselves as being relevantly different than we actually are. And this is of course often what novels and movies invite us to experiment with - to discover, through fictions, human possibilities: what we could be. But this does not always work. And it seems that fictions are telling us something when we find ourselves impervious to the possibilities that they offer. Fictions are, in short, sometimes non-starters where certain possibilities are concerned. Some philosophers - those who consider that we decide to make-believe - exaggerate our ability to make-believe. Sometimes we simply cannot do so, being unable to imagine that things could proceed as presented in a certain sort of novel or film.

Theological fictionalism must explain to us why we make-believe in God if we do not have to believe in him. But that we make-believe in Him - in His story, that His son died for us, in the resurrection of the flesh, and so on - is not easier to understand than the fact that people really believe these things. And so, theological fictionalism is not in any way a better epistemological position from which to explain the religious stance than is theological realism, and is a far worse position from which to raise questions of justification!

\section{CONCLUSION}

Theological fictionalism could perhaps pretend to be simply an account of the cultural dimension of Christian religion. It would certainly possible to visit Roman churches and Gothic cathedrals with our children, and to say to them: "Look at these wonderful works of art, my dears! Appreciate 
all of this beauty!" The children might them ask: "But, Sir, what does all this mean: all these crosses, the statues, and all the rest?" - "Well, dear children, you must make-believe a certain story to make sense of all this. It is a very long story, contained in a very big book called "The Bible", and I will simply tell you the main episodes. For example, it is said in this story that God had a son, named Jesus Christ, and that he was crucified to save all Humanity from death. Don't laugh, Immanuel, this has a profound meaning; and if you look at these works of art as if it there were a God, and a Son of God who died for us, you will be intensely moved by everything you see around you. Do the same as you do when you watch a Superman adventure on TV!" This would be cultural initiation. And for such an initiation, we could perhaps do with simulation. Looking at Yoruba sculptures of twins, I can simulate, in a sense, the kind of beliefs traditional Yorubas had about twins. But it is exactly because I do not have those beliefs that I can simulate them. If I do believe, I do not simulate, but share the Yorubas' vision. 